\title{
Particleboards produced with different proportions of Hevea brasiliensis: Residual wood valorization in higher value added products
}

\section{Placas aglomeradas produzidas com diferentes proporções de Hevea brasiliensis: Valorização da madeira residual em produtos de maior valor agregado}

\author{
Douglas Lamounier Faria1*(iD), Tony Matheus Carvalho Eugênio² (D), Daiane Erika Lopes $^{2}$ (D), \\ Thiago de Paula Protásio ${ }^{3}$ (D) , Lourival Marin Mendes² (iD) , José Benedito Guimarães Junior² (iD
}

\author{
'Universidade Federal de Lavras/UFLA, Departamento de Ciências Florestais/DCF, Lavras, MG, Brasil \\ ¿Universidade Federal de Lavras/UFLA, Lavras, MG, Brasil \\ 3Universidade Federal Rural da Amazônia/UFRA, Parauapebas, PA, Brasil \\ *Corresponding author: douglas.lamounier@yahoo.com \\ Received in August 3, 2020 and approved in November 26, 2020
}

\begin{abstract}
The use of the Hevea brasiliensis tree in latex rubber production has resulted in a consolidated role of this tree in the Brazilian economy. However, at the end of the productive cycle of the tree that lasts for approximately 25 years, the timber resulting from this venture has no added value and is usually used for the production of firewood. In order to introduce this species into the furniture and civil construction industry, the current study aimed to evaluate the quality of particleboard produced by adding Pinus oocarpa wood with Hevea brasiliensis wood in different ratios. The particleboards were produced with a nominal density of $0.60 \mathrm{~g} / \mathrm{cm}^{3}$ and $8 \%$ (wt\%) urea-formaldehyde resin and pressed at $160{ }^{\circ} \mathrm{C}$ for $8 \mathrm{~min}$ at a pressure of $4.0 \mathrm{MPa}$. The quality of the particleboard was evaluated by water absorption and thickness swelling, internal bonding, static bending, and screw withdrawal tests. The substitution of Pinus particles by Hevea wood resulted in decreased water absorption and thickness swelling. The boards produced with a higher proportion of Hevea had better dimensional stability due to the greater porosity of the Pinus oocarpa particles. The inclusion of Hevea brasiliensis wood resulted in a $75 \%$ increase in the modulus of rupture and a $300 \%$ increase in internal bonding compared with the particleboards produced only with Pinus oocarpa wood. The results show that Hevea brasiliensis wood could be used to obtain higher value-added products and contribute to the diversification of the raw materials used in the particleboard industries of Brazil.
\end{abstract}

Index terms: Reconstituted wood; rubber tree; furniture; waste material use.

\begin{abstract}
RESUMO
Devido ao uso dessa árvore na produção de látex, a Hevea brasiliensis tem um papel consolidado na economia brasileira. No entanto, ao final do ciclo produtivo dessa árvore, que dura aproximadamente 25 anos, a madeira resultante desse empreendimento não possui valor agregado e é normalmente utilizada na produção de lenha. Buscando introduzir esta espécie na indústria moveleira e da construção civil, este estudo objetivou avaliar a qualidade de painéis aglomerados produzidos com madeira de Pinus oocarpa misturada com madeira de Hevea brasiliensis em diferentes proporções. Os painéis aglomerados foram produzidos com uma densidade nominal de $0,60 \mathrm{~g} / \mathrm{cm}^{3}$ e $8 \%$ de adesivo uréia-formaldeído e prensados a $160{ }^{\circ} \mathrm{C}$ por 8 minutos a uma pressão de 4,0 MPa. A qualidade dos painéis aglomerados foi avaliada pelos testes de absorção de água e inchamento em espessura, ligação interna, flexão estática e arrancamento de parafusos. A substituição das partículas de Pinus por Hevea resultou em decréscimo da absorção de água e do inchamento em espessura. Os painéis produzidos com maior proporção de Hevea apresentaram melhor estabilidade dimensional devido à maior porosidade das partículas de Pinus oocarpa. A inclusão da madeira de Hevea brasiliensis resultou em um aumento de $75 \%$ no módulo de ruptura e um aumento de $300 \%$ na ligação interna em comparação com os painéis de partículas produzidos apenas com madeira de Pinus oocarpa. A madeira de Hevea brasiliensis pode ser utilizada para obter produtos de maior valor agregado e contribuir para a diversificação das matérias-primas utilizadas nas indústrias brasileiras de painéis aglomerados.
\end{abstract}

Termos para indexação: Madeira reconstituída; árvore de borracha; mobília; uso de resíduos. 


\section{INTRODUCTION}

Generally, Brazilian industries use wood from planted forests for the production of particleboard, particularly wood from the genus Pinus and Eucalyptus. The selection of wood determines the quality of the product (Sekaluvu et al., 2013; Kowaluk et al., 2020). However, according to Teodoro et al. (2016), with the growth of the sector from 55 million $\mathrm{m}^{3}$ in 1995 to 95 million $\mathrm{m}^{3}$ in 2017 (Food and Agriculture Organization of the United Nations - FAO, 2019), it has become necessary to search for new species that can contribute to the requirements of the industries and the development and creation of new products.

In this sense, the agro-industrial sector facilitates the introduction of new alternatives because this industry generates by-products and wastes with great potential for use in the particleboard industry during production cycles. Hevea brasiliensis, commonly known as the Pará rubber tree (Gomes et al., 2019), was included in tree plantations due to its immense economic importance in the production of latex rubber in Brazil (Iwakiri et al., 2017). Hevea brasiliensis is a tree species whose natural occurrence is concentrated in the Brazilian Amazon (latitude $7^{\circ} \mathrm{N}$ to 15 ${ }^{\circ} \mathrm{S}$ ) but is cultivated in several states of the country.

According to the annual report of the Brazilian Tree Industry (Brazilian Tree Industry - IBÁ, 2017), the total area planted with rubber trees in Brazil reached 229,964 ha in 2016; this represented an increase of 905 ha compared with 2015. After the production cycle of about 25 years, approximately 200 trees/ha or 200 to 250 $\mathrm{m}^{3} / \mathrm{ha}$ are available for cutting and commercial use. It is the third most planted species in the country. After rubber extraction, the wood has no specific purpose and is used almost exclusively for firewood and charcoal (Eufrade Junior et al., 2015). One of the ways to optimize the use of Hevea brasiliensis from plantations is to obtain multiple products. The use of wood, which was previously almost entirely wasted, has been an important complementary alternative (Muzel et al., 2014; Iwakiri et al., 2017).

The use of residual biomass is the focus of several studies involved in the manufacture of particleboard. Examples include the use of palm trunk residues by Baskaran et al. (2017), the use of sugarcane bagasse and Amazonia vegetable fibers (curaua and jute) (Fiorelli et al., 2018), and the use of coir fibers and waste banana stem fibers (Wang; Hu, 2016). However, the literature lacks information on the use of Hevea brasiliensis wood as a raw material in the construction of particleboard. This fact is attributed to the intrinsic characteristics of the lignocellulosic material used that directly influence the physical and mechanical properties of the particleboard. The promotion of sustainable development strategies was highlighted by the introduction of the waste management structure that favors practices that prolong the life cycle of waste (Vakalis et al., 2018). Therefore, studies related to the disposal of waste from particleboard production are relevant.

Several researchers have investigated different combinations of species for the production of particleboards. For example, Bufalino et al. (2012) substituted Pinus oocarpa particles for Toona ciliata and observed an improvement in the physical and mechanical properties of the particleboard produced. Iwakiri et al. (2018) evaluated the quality of medium-density particleboard produced with Hevea brasiliensis wood mixed with three Eucalyptus species. They achieved satisfactory physical and mechanical properties indicating the potential for the use of this species in mixtures with other forest species. Kowaluk et al. (2020) studied wood from Prunus domestica L. and Malus domestica Borkh. instead of Pinus sylvestris L. wood and concluded that the species had the potential for particleboard production. However, there is a need for in-depth studies on the use of Hevea brasiliensis wood for the partial and total replacement of other traditional genera used in the production of particleboard like Pinus. Thus, the use of by-products generated in the rubber tree production chain for particleboard production benefits the increase in family income by the generation of jobs, and consequently, improvement of the sustainability in the circular bioeconomy context.

Therefore, this study aims to evaluate the quality of particleboards produced with Pinus oocarpa wood mixed with Hevea brasiliensis in different ratios.

\section{MATERIAL AND METHODS}

\section{Collection and characterization of Pinus oocarpa and Hevea brasiliensis}

The particleboards were produced using wood from Pinus oocarpa and Hevea brasiliensis (clone $\mathrm{Pb} 235$ ) aged 28 and 35 years, respectively. The woods were collected from the campus of the Federal University of Lavras (UFLA) located in the municipality of Lavras in the southern region of Minas Gerais, Brazil; the coordinates are $21^{\circ} 14^{\prime} 45^{\prime \prime} \mathrm{S}, 44^{\circ} 59^{\prime} 59^{\prime \prime} \mathrm{W}$, and the altitude is 920 $\mathrm{m}$. Two trees of each species were cut, and 0.60-m-long logs were removed from the bases of each tree. The wood veneers were obtained by a rotary veneer lathe after heating 
the logs at $70{ }^{\circ} \mathrm{C}$ for a period of $24 \mathrm{~h}$ in water according to the recommendations of Iwakiri (2005).

The logs were then sliced by a rotary veneer lathe producing wood veneers with a nominal thickness of $2 \mathrm{~mm}$. The veneers were dried in an oven at $105 \pm 2{ }^{\circ} \mathrm{C}$ for $24 \mathrm{~h}$ to reduce the moisture to a final value of $3 \%$. After drying, the veneers were processed in a hammer mill to obtain sliver particles. Subsequently, the particles were sieved using a vibrating sieve. The particles retained between the 10 mesh $(2.00 \mathrm{~mm})$ and 30 mesh $(0.595 \mathrm{~mm})$ sieves only were used in the particleboards production.

Before the production of the particleboard, both species were characterized according to their basic densities following the guidelines of standard NBR 7190 (Brazilian Association of Technical Standards - ABNT, 1997). The levels of total extractives were obtained according to standard NBR 14853 (ABNT, 2010). The ash content by standard NBR 13999 (ABNT, 2017), and insoluble lignin was determined by standard NBR 7989 (ABNT, 2010). The tests to obtain the basic density and chemical constituents were carried out in triplicate.

The anatomical structure of rubberwood was evaluated as follows: the samples were saturated in water; and transverse, radial, and tangential sections (at thicknesses of 12-20 $\mu \mathrm{m}$ ) were cut using a microtome Leica SM 2000R. The sections were washed, dehydrated, and stained with $1 \%$ hydro-alcoholic safranin and astra blue and fixed on permanent slides with Entellan. Photomicrographs were obtained from the in natura sections, and the permanent slides by an optical microscope Olympus BX41TF coupled to the computer using the software Wincell. The descriptions were made in accordance with the International Association of Wood Anatomists - IAWA Committee (1989).

\section{Production of particleboards}

For bonding of the particles, a urea-formaldehyde adhesive was used with a $60 \%$ solid content ( $\mathrm{wt} \%$ ), a viscosity of $0.20095 \mathrm{~Pa} . \mathrm{s}$, and $\mathrm{pH}$ of 8.45 . The adhesive content $(8 \%)$ was used based on the dry mass of the particles in each board.

The particleboards were produced with dimensions of $300 \times 300 \times 15 \mathrm{~mm}$ and a nominal density of $0.60 \mathrm{~g} / \mathrm{cm}^{3}$. Five different compositions were evaluated by replacing different percentages of Pinus oocarpa particles with Hevea brasiliensis wood particles. Each composition had three replicates (three particleboards) totaling 15 particleboards. The different percentages of Hevea brasiliensis used in the five treatments are described in Table 1.
Table 1: Composition of the particleboards.

\begin{tabular}{cc}
\hline Abbreviation & $\begin{array}{c}\text { Pinus oocarpa } \\
+ \\
\text { Hevea brasiliensis }\end{array}$ \\
\hline P100/H0 & $100 \%+0 \%$ \\
P75/H25 & $75 \%+25 \%$ \\
P50/H50 & $50 \%+50 \%$ \\
P25/H75 & $25 \%+75 \%$ \\
P0/H100 & $0 \%+100 \%$ \\
\hline
\end{tabular}

The particleboards were pressed at a temperature of $160{ }^{\circ} \mathrm{C}$ and a specific pressure of $4.0 \mathrm{MPa}$ for 8 min. They were then placed in a climatic chamber at a temperature of $20 \pm 3{ }^{\circ} \mathrm{C}$ and relative humidity of $65 \pm 5 \%$ until it reached equilibrium moisture of approximately $12 \%$ and achieved complete curing of the adhesive.

\section{Analyses of the physical and mechanical properties of the particleboards}

The compression ratio (CR) of each particleboard was calculated by dividing the bulk density of the particleboard by the basic density of the Hevea brasiliensis and Pinus oocarpa wood (Equation 1) as described by Guimarães Junior et al. (2016) and Scatolino et al. (2017).

$C R=\frac{b d}{h b d x(h b \%)+p o d x(p o \%)}$

where: bd is the bulk density of the particleboard $\left(\mathrm{g} / \mathrm{cm}^{3}\right)$, hbd is the basic density of Hevea brasiliensis wood (g/ $\left.\mathrm{cm}^{3}\right), \mathrm{hb} \%$ is the wood content of Hevea brasiliensis, pod is the basic density of Pinus oocarpa wood $\left(\mathrm{g} / \mathrm{cm}^{3}\right)$, and po $\%$ is the wood content of Pinus oocarpa.

For evaluation of the physical and mechanical properties of the particleboards produced, the tests described in Table 2 were performed.

For a better understanding of the adhesion that occurred in the boards, specimens with dimensions of $6 \mathrm{~mm}$ diameter and $3 \mathrm{~mm}$ thickness were removed from the areas that ruptured during the static bending test and evaluated by scanning electron microscopy (SEM). The specimens were covered with a gold layer in a sputter coater and analyzed using SEM (LEO EVO $40 \mathrm{XPV}$ ) operating at $20 \mathrm{kV}$ to obtain the scanning electron micrographs. 
Table 2: Tests performed on the particleboard, size of the test specimens, number of test specimens, and standards used.

\begin{tabular}{cccc}
\hline Test & $\begin{array}{c}\text { Size of the } \\
\text { specimens }(\mathrm{mm})\end{array}$ & $\begin{array}{c}\text { Number of } \\
\text { specimens }\end{array}$ & Standard \\
\hline Moisture & $50 \times 50$ & 5 & NBR 14810-2 (ABNT, 2018) \\
WA2 h, WA24 h, TS2 h and TS24 $\mathrm{h}$ & $50 \times 50$ & 5 & D-1037-12 (ASTM, 2012) \\
MOR and MOE & $250 \times 50$ & 3 & DIN-52362 (1982) \\
Internal bonding & $50 \times 50$ & 5 & NBR 14810-2 (ABNT, 2018) \\
Screw withdrawal (face and top) & $50 \times 50$ & 6 & NBR 14810-2 (ABNT, 2018) \\
\hline
\end{tabular}

WA2 $\mathrm{h}$ is the water absorption after $2 \mathrm{~h}$ of immersion; WA24 $\mathrm{h}$ is the water absorption after $24 \mathrm{~h}$ of immersion; TS2 $\mathrm{h}$ is the thickness swelling after $2 \mathrm{~h}$ of immersion; TS24 $\mathrm{h}$ is the thickness swelling after $24 \mathrm{~h}$ of immersion; MOR is the modulus of rupture, and MOE is the modulus of elasticity at static bending.

To evaluate the properties of the studied woods, the data were subjected to analysis of variance (ANOVA). The results obtained for the physical and mechanical properties of the boards were subjected to ANOVA, and when significant, to linear or quadratic regression analysis, both at a significance level of $5 \%$. The data were processed using the SISVAR 5.6 software (Ferreira, 2014).

\section{RESULTS AND DISCUSSION}

\section{Physical and chemical characterization of Pinus oocarpa and Hevea brasiliensis wood}

The mean basic density of the Pinus oocarpa wood was $0.477( \pm 0.01) \mathrm{g} / \mathrm{cm}^{3}$. This value was close to that $\left(0.470 \mathrm{~g} / \mathrm{cm}^{3}\right)$ obtained by Pinati et al. (2018) for the same species. The Hevea brasiliensis wood had a mean basic density of $0.559( \pm 0.02) \mathrm{g} / \mathrm{cm}^{3}$. Similar results were obtained by Eufrade Júnior et al. (2015), who found mean basic densities of $0.553 \mathrm{~g} / \mathrm{cm}^{3}$ for clone RRIM 600 and $0.541 \mathrm{~g} / \mathrm{cm}^{3}$ for clone GT 1 of the Hevea brasiliensis species. The differences observed between the basic densities of the two species were due to numerous factors such as the species itself, age of the trees, and anatomical structure given that Pinus is a conifer and Hevea is a hardwood.

The Hevea brasiliensis and Pinus oocarpa species studied here can be classified as possessing medium ( $>$ $\left.0.5 \mathrm{~g} / \mathrm{cm}^{3}\right)$ and low density $\left(<0.5 \mathrm{~g} / \mathrm{cm}^{3}\right)$, respectively. Medium-to-low specific mass woods are most suitable for the production of wood particleboard due to the ease of producing the veneers. Thus, the feasibility of studying these two species was ensured (Moslemi, 1974).

All the constituents differed significantly in the chemical properties of the wood (Table 3). The differences observed were attributed to the peculiarities of each species because Pinus oocarpa is a conifer, and Hevea brasiliensis is a hardwood. Conifers have a higher content of extractives and lignin, while hardwoods have higher percentages of holocellulose in their cell walls (Collard; Blin, 2014; Wang et al., 2017). The presence of higher levels of extractives tends to hinder the process of bonding in the particleboards. However, the higher lignin levels are important to improve the adhesion quality in particleboards.

Pinus oocarpa wood exhibited the highest levels of extractives. High levels of extractives may influence the cure time of the adhesive and the adhesion quality (Boa et al., 2014). Depending on the species and the drying conditions of the wood, due to migration and excessive concentration of extractives, a so-called "inactive or contaminated surface" may occur, hindering the adhesivewood contact (Iwakiri, 2005). This behavior was observed by Klímek et al. (2018) when they evaluated particleboards produced with Miscanthus particles. They concluded that the poor results for the properties evaluated were due to the high extractive content of the raw material used (27\%). Similar behavior was observed by Mesquita et al. (2018) in particleboards produced using Euterpe oleracea Mart. fibers treated with $0.5 \% \mathrm{NaOH}$. Improved dimensional stability and improved mechanical properties were observed with treated fibers compared with the fibers without alkaline treatment.

The lignin content of Pinus oocarpa wood was $26.08 \%$, whereas that of Hevea brasiliensis wood was $14.64 \%$. Riyaphan et al. (2015) obtained a lignin content of $21 \%$ for the Hevea brasiliensis clone RRIM 600 at 13 years of age. The lower lignin concentrations obtained in the present study may be attributed to factors such as the group of each species (Pinus is a conifer, while Hevea is a hardwood), tree age, characteristics of the region where the 
trees were collected, climatic conditions, and particularly the specificities of the studied clone. Lignin is a natural adhesive and optimal for the production of reconstituted wood panels; it provides better mechanical properties and water resistance due to its hydrophobic characteristics (Matsuhita, 2015; Boon et al., 2019).

The ash contents were $0.26 \%$ for Pinus oocarpa wood and $1.56 \%$ for Hevea brasiliensis wood. These values are considered low and probably do not inhibit the adhesion process or the mobility of the adhesive in the wood.

\section{Physical properties of the particleboard}

Table 4 shows the mean values for the bulk density, compression ratio, and moisture (on a dry basis) of the particleboards.

The values obtained for the bulk densities of the particleboards ranged from 0.517 to $0.529 \mathrm{~g} / \mathrm{cm}^{3}$; no statistical significance was observed at $5 \%$ by the Tukey's test. All the particleboards produced were classified as low density $\left(<0.60 \mathrm{~g} / \mathrm{cm}^{3}\right.$ and $<0.64 \mathrm{~g} /$ $\mathrm{cm}^{3}$, respectively) according to the standards CS 236-66 (1968) and ANSI A208.1 (2016). The low bulk density observed in the current study can be attributed to the specific circumstances of the laboratory conditions relative to the industrial process. These include the loss of materials in the handling of the particles during the adhesive application, mat forming, and pressing steps of the particleboards, as reported by Scatolino et al. (2017), Soares et al. (2017), and Martins et al. (2018). Furthermore, the decrease in the density compared with the nominal value may be due to the "springback" of the particleboards after removal from the hot press and storage; thus, leading to a consequent increase in the volume of the particleboards and reduction in the bulk density after acclimation (Mendes et al., 2014; Andrade et al., 2018). However, this result does not compromise the interpretations proposed in this research.

A lower bulk wood density, according to several authors, implies particleboards with higher compression ratios (Scatolino et al., 2013; Guimarães Junior et al., 2016; Scatolino et al., 2017). Guimarães Junior et al. (2016), Soares et al. (2017), and Andrade et al. (2018) reported results similar to those of the current study with compression ratios below 1.3.

The moisture content ranged from 7.30 to $7.59 \%$ and the treatments did not differ significantly. The Brazilian standard NBR 14810-2 (ABNT, 2018) stipulates moisture values between 5 and $11 \%$. Therefore, all the compositions were within the range defined by the standard.

The water absorption values were fitted as a function of an increase in the percentage of Hevea brasiliensis wood after 2 and $24 \mathrm{~h}$ of immersion in water. The regression model for these values is shown in Figure 1. The water absorption decreased after 2 and $24 \mathrm{~h}$ of immersion as the ratio of Hevea brasiliensis particles in the particleboards increased. This reduction in water absorption could be explained by the presence of a greater number of empty spaces in the Pinus oocarpa wood, which is the cause of the lower basic density of this species, compared with that of the Hevea brasiliensis wood. Figure 2 refers to the particleboards produced with Pinus oocarpa particles only and illustrates the presence of pits observed in the scanning electron micrographs.

Table 3: Chemical composition of Pinus oocarpa and Hevea brasiliensis woods.

\begin{tabular}{cccc}
\hline Material & Total extractives $(\% \mathrm{db})$ & Insoluble lignin $(\% \mathrm{db})^{\star}$ & Ash $(\% \mathrm{db})$ \\
\hline Pinus oocarpa & $4.03 \pm 0.17 \mathrm{~B}$ & $26.08 \pm 2.50 \mathrm{~B}$ & $0.26 \pm 0.02 \mathrm{~A}$ \\
Hevea brasiliensis & $3.17 \pm 0.44 \mathrm{~A}$ & $14.64 \pm 0.20 \mathrm{~A}$ & $1.56 \pm 0.07 \mathrm{~B}$ \\
\hline
\end{tabular}

*based on extractive-free mass. Different letters within columns indicate statistical differences according to the $F$ test $(p<0.05)$.

Table 4: Bulk density, compression ratio, and moisture of the particleboards.

\begin{tabular}{cccc}
\hline Composition & Bulk density $\left(\mathrm{g} / \mathrm{cm}^{3}\right)$ & Compression ratio & Moisture $(\% \mathrm{db})$ \\
\hline T1 $-\mathrm{P} 100 / \mathrm{H} 0$ & $0.521 \pm 0.019$ & $1.09 \pm 0.07$ & $7.37 \pm 0.14$ \\
T2 - P75/H25 & $0.529 \pm 0.036$ & $1.06 \pm 0.05$ & $7.30 \pm 0.13$ \\
T3 - P50/H50 & $0.517 \pm 0.041$ & $0.99 \pm 0.02$ & $7.43 \pm 0.25$ \\
T4 - P25/H75 & $0.527 \pm 0.006$ & $0.97 \pm 0.06$ & $7.59 \pm 0.17$ \\
T5 - P0/H100 & $0.525 \pm 0.018$ & $0.93 \pm 0.03$ & $7.42 \pm 0.20$ \\
\hline
\end{tabular}




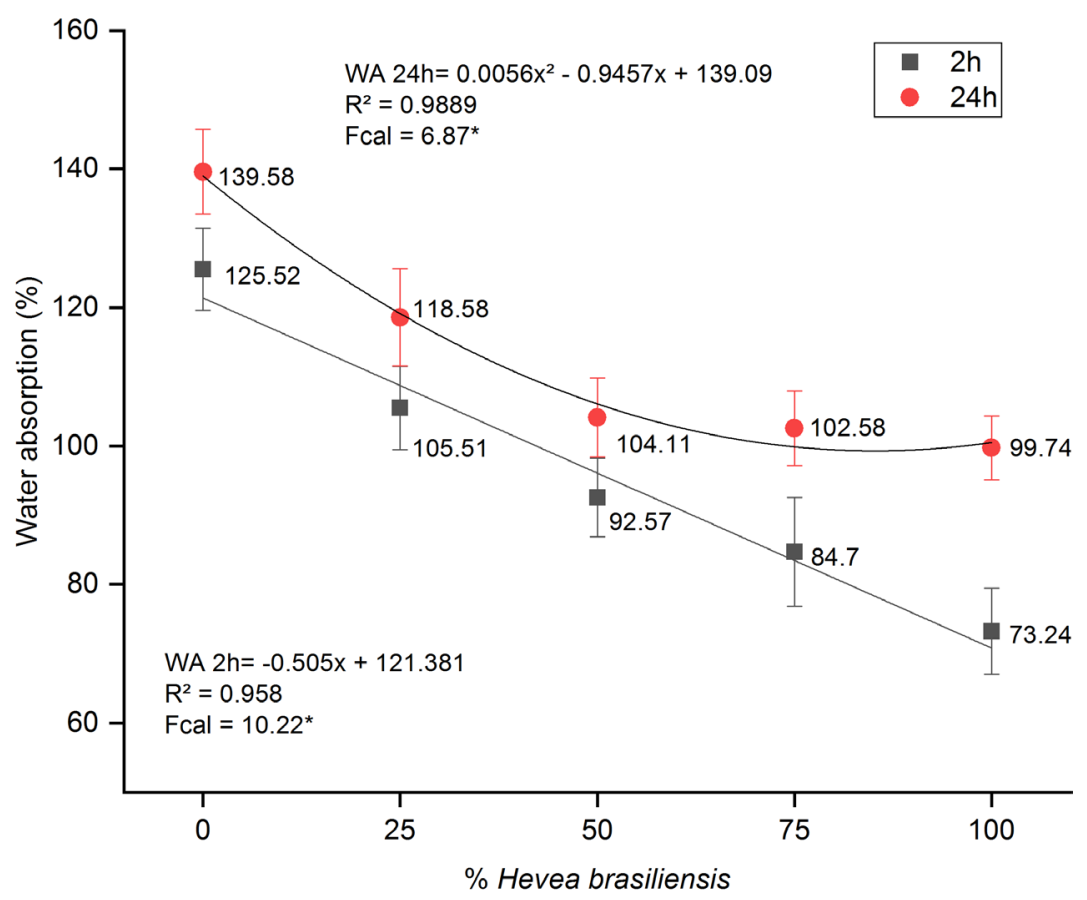

Figure 1: Water absorption after 2 and $24 \mathrm{~h}$ of immersion of the particleboard. *significant at the $5 \%$ significance level.

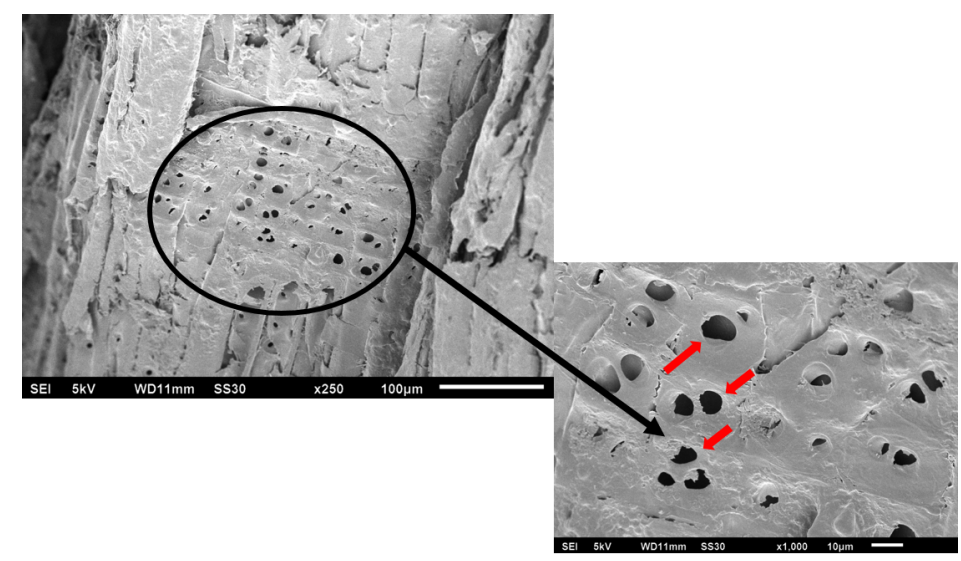

Figure 2: Scanning electron micrographs of the Pinus oocarpa wood particles where red arrows indicate the presence of pits.

The scanning electron micrographs shown in Figure 2 corroborated the results shown in Figure 1. They revealed that when the particles of Hevea brasiliensis were added to the particleboard, the water absorption decreased due to the anatomical differences between the raw materials used in the production of these kinds of particleboards. The presence of pits in the Pinus oocarpa wood tracheids (Figure 2) facilitated the absorption and adsorption of water. This was in contrast to the situation in Hevea brasiliensis that had libriform fibers with very few simple pits. Figure 3 shows that the lower water absorption levels of the particleboards produced with a higher ratio of Hevea brasiliensis wood were justified by the presence of tyloses in the vessels of this species. The tyloses are generally present in the heartwood and serve as a barrier for water inflow. Another aspect to consider 
was the porosity: the Hevea brasiliensis wood showed the highest mean specific mass. The higher the wood density is, the smaller the number of voids in the wood is and vice versa. Thus, this observation justified the results obtained for the physical properties of the particleboards.

Contrary to the results of the current study, Iwakiri et al. (2018) analyzed the feasibility of using Hevea brasiliensis (Clone RRIM 600) in a mixture with three species of Eucalyptus used in the industries of São Paulo for the production of particleboard. They obtained values ranging from 13.45 to $26.52 \%$ for water absorption after $2 \mathrm{~h}$ of immersion in water and 61.06 to $76.77 \%$ for water absorption after $24 \mathrm{~h}$. The increased mean water absorption values observed by these authors were due to the greater specific mass of the Hevea brasiliensis wood and the consequent reduction in the compression ratio of the particleboards facilitating the water inflow. Furthermore, the higher water absorption observed in the current study compared to that of Iwakiri et al. (2018), for Hevea brasiliensis, could be due to the lack of using paraffin in the formulation of the particleboards because this emulsion reduces the hygroscopicity of the wood.

The relationship between TS2 h and TS2 $4 \mathrm{~h}$ and the percentage of Hevea brasiliensis wood used indicated significant linear regression for both properties (Figure 4): a decrease in the mean values was observed with an increase in the amount of Hevea brasiliensis wood used. Figure 4 shows a decrease in the percentage of thickness swelling after 2 and 24 $\mathrm{h}$ of immersion in water as the addition of Hevea brasiliensis particles increased; this yielded the lowest thickness swelling value of $10.14 \%$ after immersion at 2 and $24 \mathrm{~h}$.

The decreasing trend observed in the present study for thickness swelling was corroborated by Trianoski et al. (2013) when Cryptomeria japonica wood was used in different ratios for the production of particleboards of pure composition or those prepared in combination with Pinus spp. The authors obtained mean values ranging from 5.71 to $3.55 \%$ after $2 \mathrm{~h}$ of immersion in water and from 18.61 to $7.85 \%$ after $24 \mathrm{~h}$ of water immersion.
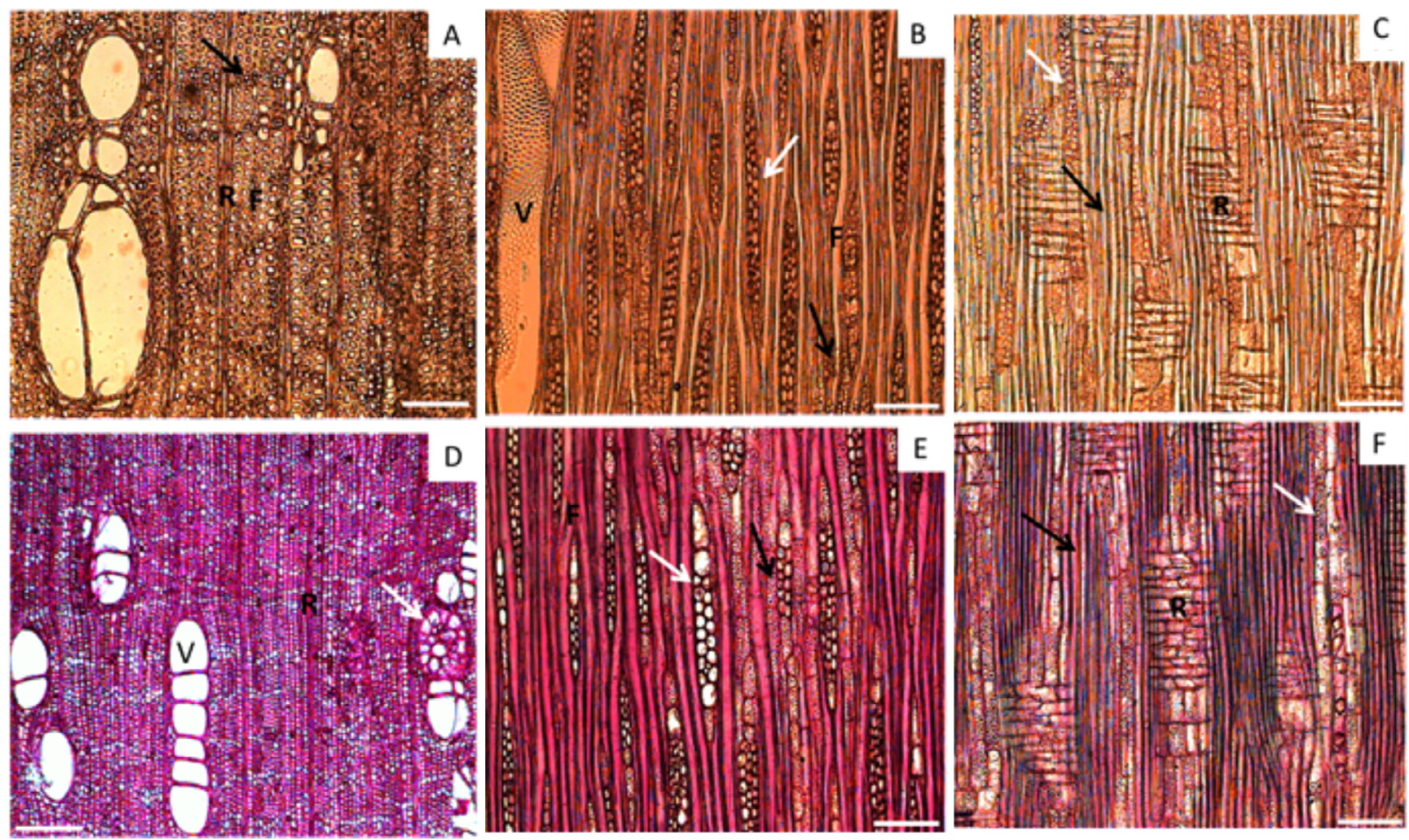

Figure 3: The higher the wood density is, the smaller the number of voids in the wood is and vice versa $(A, D)$ Cross-sections of the Hevea brasiliensis wood: the vessels (V), fibers (F), rays (R), apotracheal axial parenchyma (arrow), and tylose (white arrow) are labeled. (B, E) tangential longitudinal sections of the Hevea brasiliensis wood: the vessel element (V), fibers (F), rays (white arrow), and axial parenchyma (black arrow) are labeled. (C, F) radial longitudinal sections of the Hevea brasiliensis wood: the fibers (black arrow), rays (R), and axial parenchyma (white arrow) are labeled. (A-C) Photomicrographs of in natura sections and (D-F) photomicrographs of sections of the permanent slides. Scale bars: $A-C=200 \mu \mathrm{m}, \mathrm{D}-\mathrm{F}=100 \mu \mathrm{m}$. 


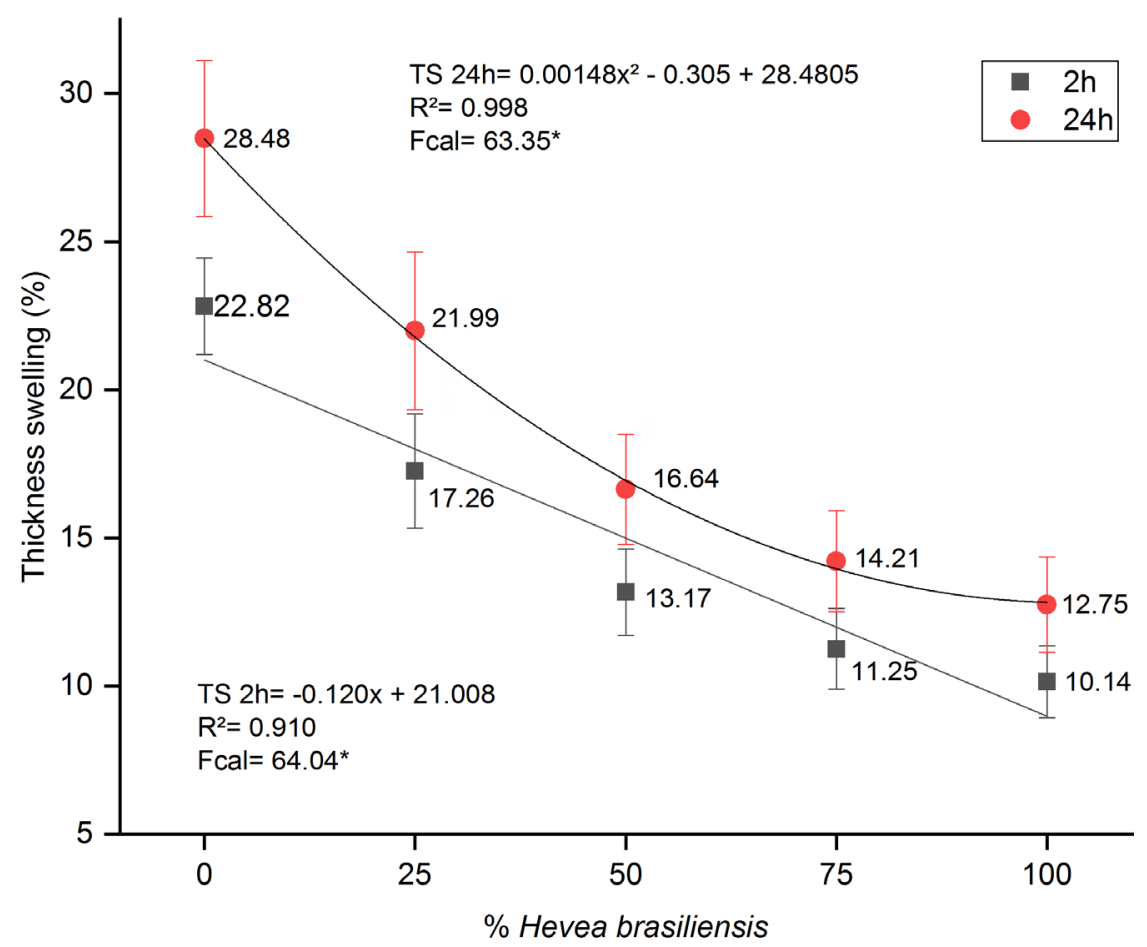

Figure 4: Thickness swelling after 2 and $24 \mathrm{~h}$ of immersion of the particleboard.

*significant at the $5 \%$ significance level.

The reduction in swelling thickness after 2 and $24 \mathrm{~h}$ of immersion in water could be explained by the greater porosity and the presence of numerous pits in the Pinus oocarpa wood (Figure 2) and the presence of tyloses in the Hevea brasiliensis wood vessels (Figure 3), which hindered the absorption of water and resulted in less thickness swelling. All the treatments evaluated satisfied the maximum of $30 \%$ specified in the standards CS 236-66 (1968) and ANSI A208.1 (2016) for thickness swelling after $24 \mathrm{~h}$ of immersion in water for low-density particleboard.

\section{Mechanical characterization of the particleboards}

Figure $5 \mathrm{a}$ shows the mean modulus of elasticity (MOE), and Figure 5b shows the mean moduli of rupture (MOR) of the particleboards produced with the species under study. The mean MOE values ranged from 934.75 MPa to $1105.92 \mathrm{MPa}$, wherein the particleboards produced using $100 \%$ Pinus oocarpa exhibited the lowest mean value, and those produced using $75 \%$ Pinus oocarpa and $25 \%$ Hevea brasiliensis showed the highest mean value. An increasing trend was observed for the MOE values when up to $50 \%$ of Pinus wood was replaced and a decreasing trend was observed for $75 \%$ and $100 \%$ replacement.
The MOE results obtained in this study are compatible with the values reported in the literature. Soares et al. (2017) obtained mean values between 250 and $700 \mathrm{MPa}$ for low-density particleboards produced with Eucalyptus grandis wood and sugarcane bagasse at different ratios. The results of the current study were slightly lower than those of Iwakiri et al. (2018). The authors obtained mean MOE values ranging from 2205 to $2725 \mathrm{MPa}$ for different combinations of the abovementioned species. The mean bulk density observed by the authors ranged from 0.728 to $0.761 \mathrm{~g} / \mathrm{cm}^{3}$, while the mean values observed for this property ranged from 0.517 to $0.529 \mathrm{~g} / \mathrm{cm}^{3}$ in the current study. Thus, higher densities resulted in higher values of the mechanical properties.

For the MOR, the mean values ranged from 5.63 MPa for the particleboards produced using $100 \%$ Pinus oocarpa particles to $9.87 \mathrm{MPa}$ for those produced using $100 \%$ Hevea brasiliensis particles. The mean MOR increased when more Hevea brasiliensis particles were added to the particleboards. In the case of the MOE, the mean values increased until $50 \%$ of the particle mass was replaced, posteriorly the values started to decrease. For the MOR, in turn, all the ratios tested exhibited increasing trends, in which the highest mean value was 
obtained for particleboards produced from $100 \%$ Hevea brasiliensis wood.

Higher values for the compression ratio most likely resulted in superior mechanical properties (Andrade et al., 2018). However, this behavior was not observed in the current study because there was no increase in the compression ratio. The increasing trend for the MOR values could be explained by the higher extractive content found for Pinus oocarpa and the anatomy of the two species studied. Extractives are highly hydrophobic chemical constituents and undesirable for good quality adhesion. According to Fonte and Trianoski (2015), particleboards produced from species with high contents of extractives may have defective bonding. The presence of two bordered pits in the tracheids of the Pinus oocarpa wood (Figure 2) may have facilitated the entry of the adhesive; thus, hampering the bonding and resulting in lower MOR values. In contrast to this, the presence of tyloses in the vessels of Hevea brasiliensis (see Figure 3) may have hindered the penetration of the adhesive in the particleboard; thus, conferring enhanced mechanical properties.

The mean MOR values for the particleboards produced using only the Pinus oocarpa wood were close to those (4.6 MPa) observed by Mendes et al. (2014). However, when comparing the treatment with $100 \%$ Hevea brasiliensis, the results obtained in this study $(9.87$ $\mathrm{MPa}$ ) were slightly lower than the mean value of 10.52 MPa found by Muzel et al. (2015). As particles of Hevea brasiliensis were added to the reconstituted panels, the particleboards displayed increased resistance, as recorded by the aforementioned authors.

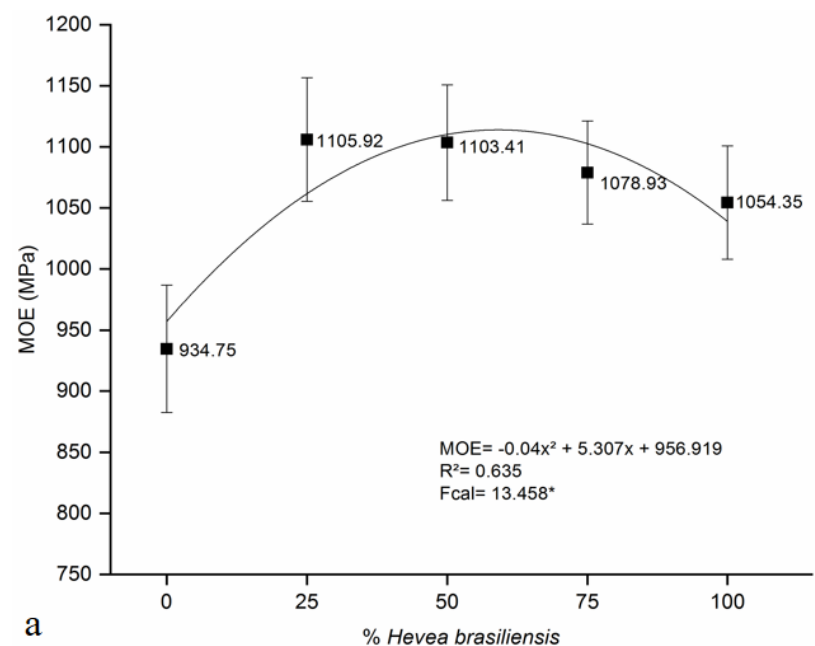

The ANSI A208.1 standard (2016) stipulated the minimum values of MOR and MOE to be 3 and 550 $\mathrm{MPa}$, respectively, for low-density particleboard. All the combinations tested met these minimum requirements. Regarding the commercial standard CS 236-66 (1968), the combination containing only $100 \%$ of Pinus oocarpa (T1) particles did not meet the minimum value of $1052.1 \mathrm{MPa}$ for MOE. However, all treatments met the requirement of a minimum value of 5.6 MPa for MOR according to the abovementioned standard.

The internal bonding test identified the internal bond to vary between 0.14 and $0.56 \mathrm{MPa}$ (Figure 6). An increase in the ratio of Hevea brasiliensis particles promoted an increase in the internal bonding that could be explained by the higher density of the particles of the Hevea species.

This increasing trend in the internal bonding was observed by Iwakiri et al. (2018) while evaluating the perpendicular tension values as a function of the increasing percentage of particles of the Hevea brasiliensis wood in the production of particleboard. They observed the highest mean values for the particleboards produced using 80 and $100 \%$ of Hevea brasiliensis particles after replacing the particles of three Eucalyptus species. According to the authors, this increase could be explained by the higher specific mass of the Hevea brasiliensis wood and the lower surface area of the particles, thus increasing the adhesive distribution. All the compositions studied met the minimum value of $0.14 \mathrm{MPa}$ for perpendicular tension according to commercial standard CS 236-66 (1968) for low-density particleboard.

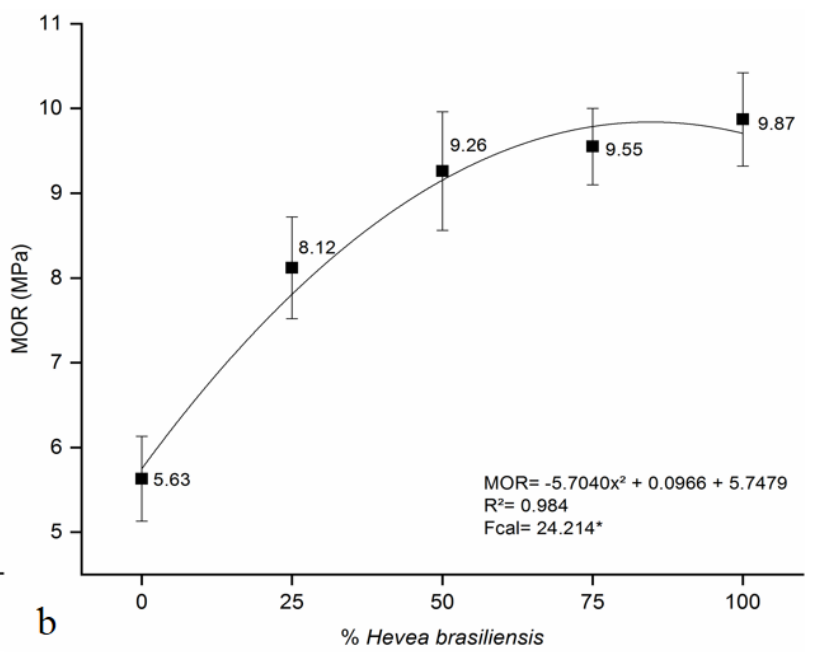

Figure 5: Modulus of elasticity (a) and modulus of rupture (b) of particleboards.

*significant at the $5 \%$ significance level. 
The regression model was fitted as a function of the percentage of Hevea brasiliensis particles, and the face and edge screw withdrawal values are shown in Figure 7.

The results of the screw withdrawal resistance tests indicated that the treatments increased the two conditions evaluated: face and top. For the face screw withdrawal, the mean values varied from $924.13 \mathrm{~N}$ for particleboards produced using $100 \%$ Pinus oocarpa wood to $1004.36 \mathrm{~N}$ for particleboards produced using $75 \%$ of Hevea brasiliensis wood. For the top screw withdrawal, the mean values ranged from $483.24 \mathrm{~N}$ for particleboards produced using $100 \%$ Pinus oocarpa wood to $650.28 \mathrm{~N}$ for particleboards produced using $100 \%$ Hevea brasiliensis wood. The results obtained for the three evaluated treatments were close to those obtained by Oliveira et al. (2016) for the two test conditions. The authors obtained mean top screw withdrawal values of 474.64, 710.0, and $520.73 \mathrm{~N}$ for the particleboards prepared from Pinus, Eucalyptus, and sugarcane bagasse, respectively. The respective mean values for the face screw withdrawal were: 438.36, 831.60, and 582.52 N (Pinus, Eucalyptus, and sugarcane bagasse).

The mean values found in the current study were lower than those obtained by Cunha et al. (2014) with a top screw withdrawal resistance of $1163.93 \mathrm{~N}$ and a face screw withdrawal resistance of $1321.06 \mathrm{~N}$. For low-density particleboard, there exist no standard established minimum values for screw withdrawal. Cunha et al. (2014) justified that the low values found for this property compared with the values observed in the literature could be attributed to the low density of the particleboards. High-density particleboards have better values for screw withdrawal resistance than medium- and low-density particleboards.

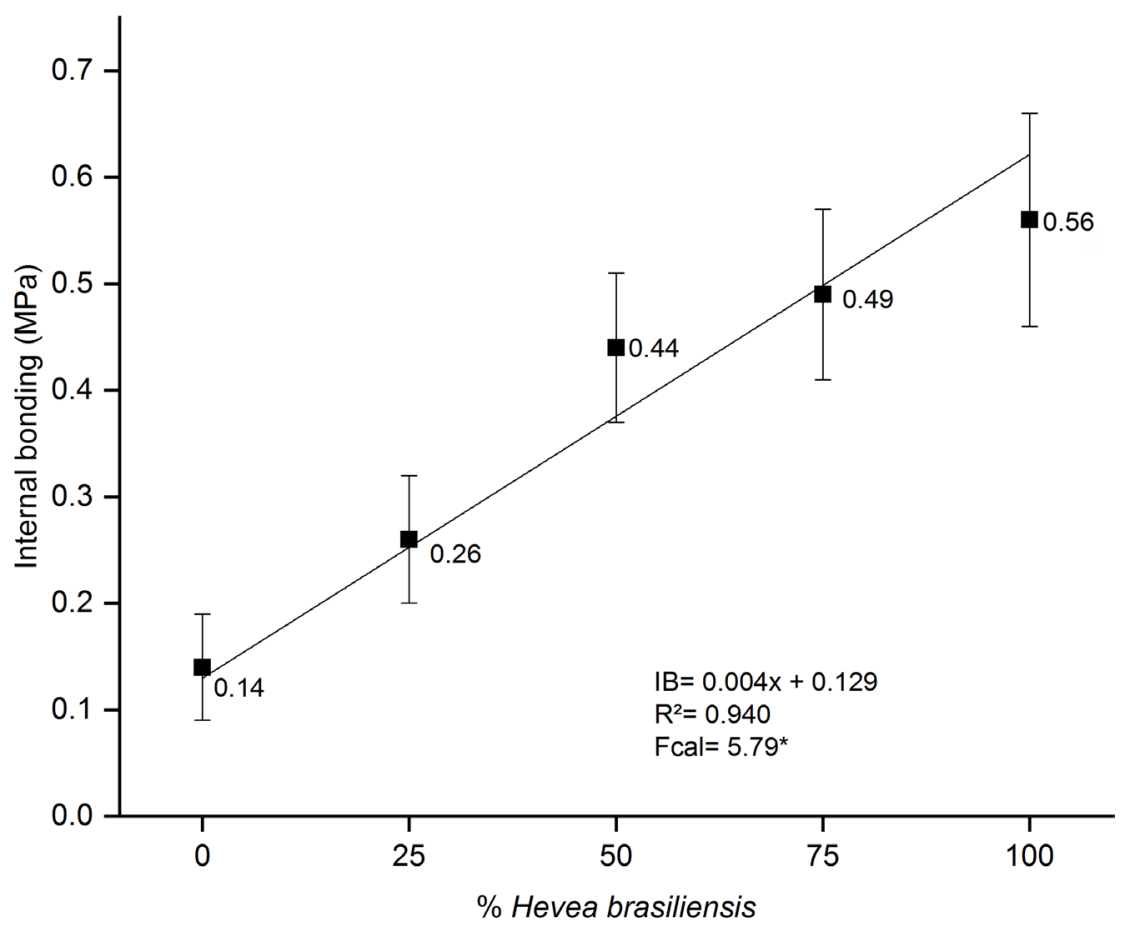

Figure 6: Mean values for the internal bonding of the particleboards.

*significant at the $5 \%$ significance level. 


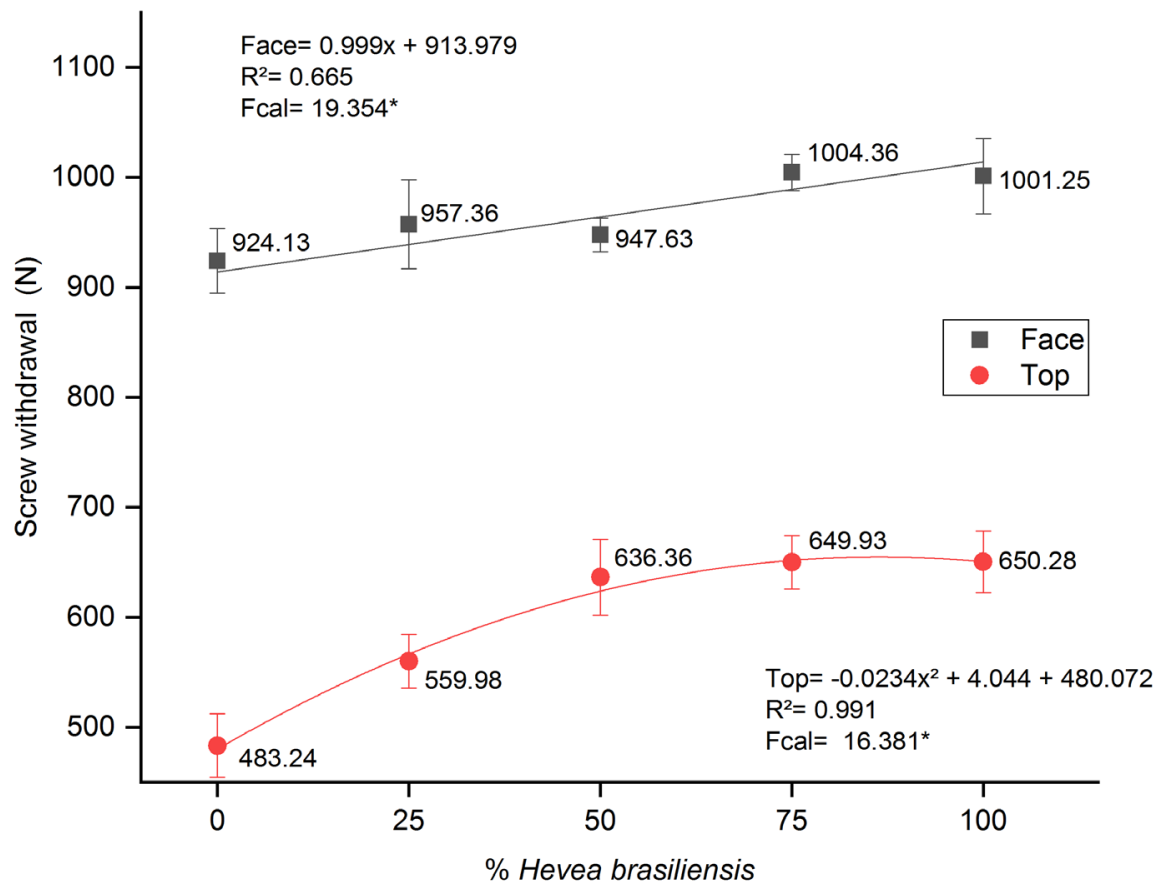

Figure 7: Mean values of screw withdrawal of the particleboards.

*significant at the $5 \%$ significance level.

\section{CONCLUSIONS}

The objective of this study was to characterize Hevea brasiliensis and Pinus oocarpa wood with respect to their physical and chemical properties. Pinus oocarpa wood had a mean basic density of $0.477 \mathrm{~g} / \mathrm{cm}^{3}$ and was classified as low-density wood, whereas Hevea brasiliensis wood is a medium-density wood $\left(0.559 \mathrm{~g} / \mathrm{cm}^{3}\right)$ and ideal for the manufacture of particleboard. There was no change in the compression ratio of the particleboards when Hevea brasiliensis particles were added to all the combinations tested. The water absorption and swelling thickness, after 2 $\mathrm{h}$ as well as $24 \mathrm{~h}$, decreased as Hevea brasiliensis particles were added. This behavior was justified by the lower specific mass of Pinus oocarpa wood, and consequently, the larger voids present in the wood and the particleboard.

The mechanical strength of the particleboards was directly affected by the inclusion of Hevea brasiliensis particles. This inclusion resulted in a $75 \%$ increase in the modulus of rupture compared with that observed in the particleboard produced using Pinus oocarpa wood alone. In general, the results observed in this study allowed the inclusion of Hevea brasiliensis as a promising species in the production of particleboard. Thus, this wood can substitute the species traditionally used in the production of reconstituted wood panels in Brazil. Moreover, the research presents technical contributions aiming to gain competitiveness of agroindustry with the residual wood valorization, after natural rubber production, waste management, and application of the circular bioeconomy in the productive chain of Hevea brasiliensis.

\section{REFERENCES}

AMERICAN NATIONAL STANDARD INSTITUTE - ANSI. Particleboard. A208.1. Gaithersburg: ANSI, 2016. Available in: <https://www.compositepanel.org/educationresources/store/standards/ansi-a2081-particleboard. html>. Access in: August, 02, 2020.

AMERICAN SOCIETY FOR TESTING AND MATERIALS - ASTM. Standard methods of evaluating properties of woodbase fiber and particles materials. D 1037-12. West Conshohocken, PA: ASTM International, 2012. Available in: <https://www.astm.org/Standards/D1037.htm>. Access in: August, 02, 2020.

ANDRADE, L. M. F. et al. Inclusion of cellulose pulping waste for production of medium density particleboards. Scientia Forestalis, 46(120):626-637, 2018. 
BASKARAN, M. et al. Properties of particleboard manufactured from oil palm trunk waste using polylactic acid as a natural binder. Waste and Biomass Valorization, 10:179-186, 2017.

BOA, A. C. et al. Eucalypts timber wastes glued with urea formaldehyde resin at room temperature. Scientia Forestalis, 42:279-288, 2014.

BOON, J. G. Physical and mechanical properties of binderless particleboard made from steam-pretreated oil palm trunk particles. Journal of Composites Science, 3(46):1-6, 2019.

BRAZILIAN ASSOCIATION OF TECHNICAL STANDARDS - ABNT. Design of wooden structures. NBR 7190. Rio de Janeiro, RJ, 1997. Available in: <https://www. abntcatalogo.com.br/ norma.aspx?|D=3395>. Access in: August, 02, 2020.

BRAZILIAN ASSOCIATION OF TECHNICAL STANDARDS - ABNT. Medium density particleboards Part 2: Requirements and test methods. NBR 14810. São Paulo, SP, 2018. Available in: <https://www.abntcatalogo.com.br/norma. aspx?ID=409718>. Access in: August, 02, 2020.

BRAZILIAN ASSOCIATION OF TECHNICAL STANDARDS - ABNT. Paper, board, pulps and wood - Determination of residue (ash) on ignition at $525^{\circ} \mathrm{C}$. NBR 13999. São Paulo, SP, 2017. Available in: <https://www.abntcatalogo.com. br/norma.aspx?ID=369837>. Access in: August, 02, 2020.

BRAZILIAN ASSOCIATION OF TECHNICAL STANDARDS - ABNT. Pulp and wood - Determination of acid-insoluble lignin. NBR 7989. São Paulo, SP, 2010. Available in: <https://www. abntcatalogo.com.br/norma.aspx?ID=57843>. Access in: August, 02, 2020.

BRAZILIAN ASSOCIATION OF TECHNICAL STANDARDS - ABNT. Wood - Determination of soluble matter in ethanoltoluene and in dichloromethane and in acetone. NBR 14853. São Paulo, SP, 2010. Available in: <https://www. abntcatalogo.com.br/norma.aspx?ID=57842>. Access in: August, 02, 2020.

BRAZILIAN INSTITUTE OF TREES - IBÁ. Annual Report. 2017. BRAZILIAN INSTITUTE OF TREES - IBÁ. Available in: <https:// iba.org/datafiles/publicacoes/pdf/iba-relatorioanual2017. pdf>. Access in: December, 08, 2020.

BUFALINO, L. et al. Particleboards made from Australian red cedar: Processing variables and evaluation of mixedspecies. Journal of Tropical Forest Science, 24(2):162172, 2012.

COLLARD, F. X.; BLIN, J. A review on pyrolysis of biomass constituents: Mechanisms and composition of the products obtained from the conversion of cellulose, hemicelluloses and lignin. Renewable and Sustainable Energy Reviews, 38:594-608, 2014.

COMMERCIAL STANDARD - CS. CS 236-66: Mat formed wood particleboard. Washington: U.S. Department of Commerce, 1968. 12p.

CUNHA, A. B. et al. Particleboard manufacture from Eucalyptus benthamii, Eucalyptus dunnii and Eucalyptus grandis. Scientia Forestalis, 42(102):259-267, 2014.

DEUTSCHES INSTITUT FUR NORMUNG - DIN. Testing of wood chipboards, bending test, determination of bending strength. 52362, 1982. 40p.

EUFRADE JUNIOR, H. J. et al. Potential of rubberwood (Hevea brasiliensis) for structural use after the period of latex extraction: A case study in Brazil. Journal of Wood Science, 61:384-390, 2015.

FERREIRA, D. F. Sisvar: A guide for its bootstrap procedures in multiple comparisons. Ciência e Agrotecnologia, 38(2):109-112, 2014.

FIORELLI, J. et al. Multilayer particleboard produced with agroindustrial waste and Amazonia vegetable fibres. Waste and Biomass Valorization, 9:1151-1161, 2018.

FONTE, A. P. N.; TRIANOSKI, R. Effect of grammage on the bonding quality of glue side of Tectona grandis wood. Revista de Ciências Agroveterinárias, 14(3):224-233, 2015.

FOOD AND AGRICULTURE ORGANIZATION OF THE UNITED NATIONS - FAO. Forestry Production and Trade, 2019.

GOMES, K. M. A. et al. Abandoned plantations of Hevea guianensis Aubl. in natural forest in the Brazilian Amazon: Methods for revitalization. Agroecossistemas, 11(2):102128, 2019.

GUIMARÃES JUNIOR, J. B. et al. Addition of sorghum culture waste in eucalyptus particleboards. Pesquisa Florestal Brasileira, 36(88):435-442, 2016.

INTERNATIONAL ASSOCIATION OFWOOD ANATOMISTS - IAWA Committee. List of microscopic features for hardwood identification. IAWA Journal. 10, p.219-332, 1989.

IWAKIRI, S. et al. Effects of particles treatments and cement accelerator admixture in the wood cement panel production. Revista Floresta, 47(3):289-296, 2017.

IWAKIRI, S. et al. Production of particleboard of Hevea brasiliensis (Clone RRIM 600) in mixture with three species of Eucalyptus used by São Paulo's industries. Scientia Forestalis, 46(117):31-39, 2018. 
IWAKIRI, S. Reconstituted wood panels. Curitiba: Editora FUPEF, 2005. 247p.

KLÍMEK, P. et al. Utilizing Miscanthus stalks as raw material for particleboards. Industrial Crops and Products, 111:270$276,2018$.

KOWALUK, G. et al. Functional assessment of particleboards made of apple and plum orchard pruning. Waste and Biomass Valorization, 11:2877-2886, 2020.

MARTINS, E. H. et al. Soybean waste in particleboard production. Ciência e Agrotecnologia, 42(2):186-194, 2018.

MATSUHITA, Y. Conversion of technical lignins to functional materials with retained polymeric properties. Journal of Wood Science, 61:230-250, 2015.

MENDES, R. F. et al. Quality of homogeneous particleboard produced with Eucalyptus urophylla clone wood. Cerne, 20(2):329-336, 2014.

MESQUITA, A. L. et al. Eco-particleboard manufactured from chemically treated fibrous vascular tissue of acai (Euterpe oleracea Mart.) fruit: A new alternative for the particleboard industry with its potential application in civil construction and furniture. Industrial Crops and Products, 112:644651, 2018.

MOSLEMI, A. A. Particleboard: Materials. London: Southern Illinois University Press, 1974. 244p.

MUZEL, S. D. et al. MDP panels manufactured with Hevea brasiliensis overlaid with bamboo foil of Phyllostachys edulis. Advanced Materials Research, 1088:686-689, 2015.

MUZEL, S. D. et al. Multilayer medium density particleboard using castor oil-based polyurethane resin and Hevea brasiliensis wood. Advanced Materials Research, 10251026:559-563, 2014.

OLIVEIRA, S. L. et al. Particleboard panels made from sugarcane bagasse: Characterization for use in the furniture industry. Materials Research, 19(4):914-922, 2016.
PINATI, E. et al. Blockboard plywood produced from Pinus oocarpa, Castilla ulei and Acrocarpus fraxinifolius. Brazilian Journal of Wood Science, 9(3):199-208, 2018.

RIYAPHAN, J. et al. Variability in chemical and mechanical properties of Pará rubber (Hevea brasiliensis) trees. ScienceAsia, 41:251-258, 2015.

SCATOLINO, M. V. et al. Eucalyptus wood and coffee parchment for particleboard production: Physical and mechanical properties. Ciência e Agrotecnologia, 41(2):139-146, 2017.

SCATOLINO, M. V. et al. Use of maize cob for production of particleboard. Ciência e Agrotecnologia, 37(4):330-337, 2013.

SEKALUVU, L. et al. Investigation of factors affecting the production and properties of maize cob-particleboards. Waste and Biomass Valorization, 5:27-32, 2013.

SOARES, S. S. et al. Valorization of sugarcane bagasse for production of low density particleboards. Brazilian Journal of Wood Science, 8(2):64-73, 2017.

TEODORO, R. et al. Functionally graded MDP panels using bamboo particles. Key Engineering Materials, 668:3947, 2016.

TRIANOSKI, R. et al. Use of Cryptomeria japonica wood for the production of particleboard. Scientia Forestalis, 41(97):5764, 2013.

VAKALIS, S. et al. Introduction to the concept of particleboard production from mixtures of sawdust and dried food waste. Waste and Biomass Valorization, 9:2373-2379, 2018.

WANG, J.; HU, Y. Novel particleboard composites made from coir fiber and waste banana stem fiber. Waste and Biomass Valorization, 7:1447-1458, 2016.

WANG, S. et al. Lignocellulosic biomass pyrolysis mechanism: A state-of-the-art review. Progress in Energy and Combustion Science, 62:33-86, 2017. 